\title{
Because individual determinants matter: a theoretical extension of Peterson's organizational employee persistence model
}

\author{
Cristina Stefania Frincu (Corresponding author) \\ Department of Psychology, Alexandru Ioan Cuza University of Iasi \\ 3, Toma Cozma street, Iasi 700554, Romania \\ E-mail: cristina.frincu@psih.uaic.ro
}

Andreea Negruti

Department of Psychology, Alexandru Ioan Cuza University of Iasi, Romania

E-mail: andreea.negruti@gmail.com

Doi:10.5296/ijhrs.v5i4.8507 URL: http://dx.doi.org/10.5296/ijhrs.v5i4.8507

\begin{abstract}
The world is changing rapidly and the need to adapt and develop presses individuals in a tremendous way to make fast personal and professional decisions in order to face the new challenges. The constant evolution at a global level inevitably translates into changes in the organizational environment, where employees need to develop their authentic professional story, need to define their goals and become competent in the decision making process regarding their career paths.

The self-perceived performance analysis, the relationships with co-workers, the employees' interest about their career growth and work-life balance proved to be strategic contributions in explaining the turnover in the Model of Organizational Persistence proposed and validated by Shari L. Peterson (2004). Our paper proposes and tests an extension of Peterson's approach by adding two more personality traits in the model: dispositional authenticity and motivational persistence, with the scope to define a more specific map of the dynamic relationships built between employees and their organization, as we believe that turnover could be managed not just directly by organizations, but also indirectly, by employees, throughout their career management decisions.

This article's findings could be valuable for both employees - who want to effectively manage their careers, and organizations, aiming to attract, understand, develop and retain talents.
\end{abstract}

Keywords: turnover, motivational persistence, professional satisfaction, dispositional authenticity, career-decision making self-efficacy 


\section{Introduction}

Employee turnover is human resources metric, as it has various with different importance levels attached. Both employees and organizational aspects impact employee turnover, either in a direct or indirect manner. Because of its complexity we believe there are two aspects which need clarification in relation with employee turnover: firstly, the organizational and workplace contextual factors that impact turnover, and secondly, the characteristics of employees determined to change the job. The recent literature provides extensive theoretical frameworks and models in the following areas: (1) new predictors for the individual differences in turnover; (2) attitudes under stress and changes; (3) empirical proves for the turnover model; (4) environmental factors regarding interpersonal relationships (like the civic interpersonal behavior); (5) factors that determine the employees to stay at a certain workplace (organizational commitment or integration in the workplace), and (6) the dynamic modeling of turnovers considering time as a factor(for example changes in the level of client satisfaction) (Boros and Curseu, 2013).

This paper treats employees and organization as two parties which exchange of intentions and expectations, goals, results and experiences, behavioral norms and assessment criteria to judge against, with the aim to generate a high level of satisfaction attached to their collaboration contract combating the intention of changing the workplace. The employee, defined by his/her socio-demographic characteristics, his/her motivational persistence, his/her career decision self-efficacy, chooses to behave in an authentic manner towards his/her colleagues and superiors and to actively contribute to the organizational performance if he/she feels accepted and integrated at work and has proofs that the organization's future actions involve his/her career development and personal welfare (the work-life balance). This approach is consistent with the organizational persistence model (Peterson, 2004) and the social-cognitive perspective (Bandura, 1997), both seeing the intention of changing the workplace as a belief that comes from a causal system with three factors that influence each other: person- environment - behavior. Employee's personality can be seen as predictive factor for the decision to change the job, while the need for achievement, for self-accomplishment and work ethic can be considered important factors in relation with the level of employee's involvement/commitment (McKnight, Phillips, Hardgrave, 2009).

\section{Turnover models}

Starting from the rational turnover models (the Model of Organizational Balance by March \& Simon, 1958 ; Meta-Expectations model by Porter \& Steers, 1973; the Intercommunications Model by Mobley, 1979), reviewing the Unfolded Model of Turnover developed by Steers \& Mowday in 1981 that treats the effect of the shock of an event and of impulsivity on turnover, and the Work Embedded in the Employee's Life Theory developed by Lee \& Mitchell in 2001, Peterson (2004) proposed a dynamic model of employee's organizational persistence. Her model tries to explain the turnover through the intercommunications system between the employee and the organization during their collaboration.

The Organizational Persistence Model (Peterson, 2004) involves a longitudinal methodological approach that recognizes the symbiotic nature of the relationship employee - 
organization, actively reflected in the employee's intentions to stay in the company or to leave. It considers the (1) evolution $\mathrm{n}$ of initial intentions of starting the collaboration with the respective company,(2) the results of the interaction between the employee's personal traits and the organizational experience and (3) integration - involving also (4) demographical factors, (5) career decision making self-efficacy as a personality factor, and (6) environmental factors (work-life balance). This model was later tested on managers from the American retail industry (2007), on governmental institution's employees (2009), and adapted for the information technology industry from Korea in 2015. Manny other studies proved the relationship between the employee-organization compatibility and work satisfaction (Kristof-Brown, Zimmerman \&Johnson, 2005; Vogel \& Feldman, 2009; Da Silva, Hutcheson \& Wahl, 2010; Christensen \& Wright, 2011; Giauque, 2014). Employee statisfaction is often relfected in his performance, his willingness to stay in the company and also in the positive comments that he/she makes about the organization he/she belongs to (Gubman, 2004).

Figure 1. Organizational Model of Employee Persistence, Shari L. Peterson, 2004

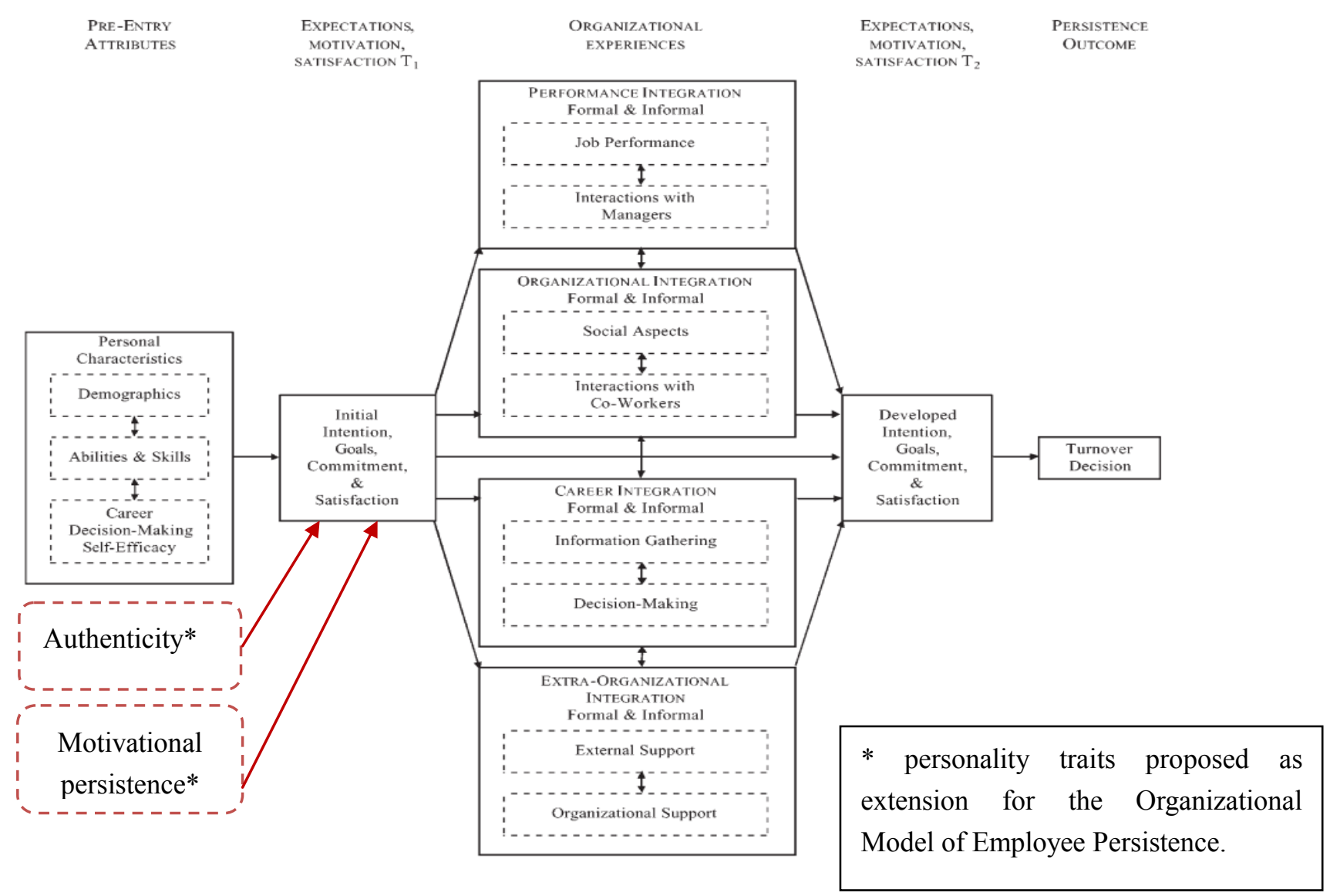

Personal characteristics are employee's specific individual aspects that define him/her when he/she starts working in an organization: demographic factors like age, gender, marital status, work experience; cognitive abilities (motivation) and behavior attributes (educational level, previous workplace performance, previous experiences). In Peterson's model, personal traits include also career decision self-efficacy. This refers to a persona's level of trust in their 
„ability to gather information and take efficient decisions regarding their career” (Peterson, 2004, p.219). Peterson states that this factor has a strong relationship with integration in the educational environment (Peterson, 1993), a strong effect on student's persistence (Peterson \& delMas, 2001), and it is related with self-efficacy and engagement in Berts's study on turnover from 2004.

Integration in organization and organizational experiences are important mainly because they represent the symbiotic and longitudinal relationship between the individual factors and the organizational traits. This interdependence appears in initial intention's influence on organizational factors, while the organizational factors having an influence on the developed intentions; organizational experience offers the frame to identify the compatibility between the employee and the work environment (needs, values, interests), specific for the starting period in the organization. Mossholder, Settoon and Henegan (2005) suggest that the integration period is critical for the collaboration's success because in that period the feeling of belonging is developed and the reciprocity feeling is activated as a result of the organizational support received. In this dynamic model, the integration is defined by positive socialization interactions between the new employee and his/her colleagues and also by the experiences gathered regarding performance, career, work-life balance; these positive experiences form the basis for connecting and belonging to the organization. The integration process refers to the employees' identity system and the attachment developed in relation with the organization. Organizational integration involves multiple levels: performance integration (socializing with managers and employees), career integration, and extra-organizational integration (work-life balance).

- Performance integration refers to the quality of task accomplishment (Cascio, 2006). In Peterson's model performance integrations refers to the employee's perception of having the necessary abilities and knowledge to successfully accomplish his/her tasks, the acknowledgement of those results and competences by the superiors and coworkers and the employee's potential development for future career opportunities. The manager plays a key role in this type of integration through his/her communication style, coordination ability, and level of interest for the development of his/her employees.

- Organizational integration reflects the level of compatibility between employee and organization, based on the quality of social interaction with superiors - celebrating the accomplishments, on personal values compatibility with those of other organizational members, on comfort level to discuss personal problems with the manager, on the manager's interest for personal and professional development of his/her employees, and on the compatibility with colleagues - having mutual support to reach the goals, sharing knowledge and effective practices, making friends, offering and receiving support for personal problems. The direct supervisor's influence on employee integration and satisfaction regarding collaboration was constantly confirmed by research (Joseph, 2007; Boswell \& all, 2009). Perceived managerial support (Maertz, 2007), encouraging interpersonal civic behavior (Mossholder, 2005), and a work environment based on trust and balance between organization's needs and employee's 
needs (Griffeth and Maertz, 2004) proved to be strong predictors for low levels of intentions to change the workplace.

- Career integration refers to the compatibility between employee's expectations regarding his/her career and the opportunities available in the organization. This match offers a sense of security and motivation for development and performance, for organizational persistence and curiosity for the future of the collaboration.

- Extra-organizational integration refers to the employee's perception that the working schedule and the organizational dynamics fit and match his/her personal life needs. External support refers to the confirmation and approvals of family and friends regarding collaboration's benefits, to the level of understanding job requirements, and to the support received to balance personal and professional responsibilities.

In the last 25 years career decision making self-efficacy proved to be a very useful concept in assessing and facilitating career development. In 1981, Betz \& Hackett explored for the first time the utility and value of this concept, to understand woman's choice in career development. Based on their different perception about the ability to display a certain behavior, women and men make different career choices. This difference in self-evaluation has its roots in personal history and role and gender stereotypical believes (each gender is taught what is appropriate or not and is encouraged to explore or to avoid certain things in order to form their gender-related abilities for a specific area of activity (Bertz, 2006).

Self-efficacy perceptions play a key role in relationship with organizational performance (meta-analysis by Staijkovic \& Luthans, 1998), task persistence (Multon, Brown and Lent, 1991), and with taking new and challenging tasks (Sexton \&Tuckman, 1991).Professional self-efficacy refers to a person's beliefs that he/she is capable to behave in the manner that the job requested (Schyns \& von Collani, 2002). Professional self-efficacy positively correlates with work satisfaction, well-being and organizational commitment (Schyns \& von Collani, 2002). Other studies used self-efficacy to analyze career exploring behaviors (Nauta, 2007).

In this paper career decision making self-efficacy is defined as employee's trust in his/hers own decisional abilities in order to take the best career decisions for him/her. This factor is a cognitive determinant for staying in the company or leaving the workplace. An employee's expectations regarding his/her own abilities will determine him/her to activate the resources he/she needs in order to accomplish his/her goals (Bandura, 2001). Bertz (2004) defines self-efficacy as the sum of a person's beliefs to successfully engage in a certain activity. Thus, high levels of self-efficacy will lead to a behavioral manifestation, while low levels will inhibit the display of certain behaviors, ruling what behaviors must be avoided. Empirical research offers consistent and significant correlations between the level of perceived self-efficacy and the level of adaptation to new work technologies (Hill, Smith \& Mann, 1987), learning new abilities (Mitchell and al., 1994), and adapting to a new workplace (Sacks, 1998).

Talent attraction, motivation, development and retention represent a current concern for any management system focused on success. In a complex and dynamic work market in which 
companies constantly invest large budgets in retention and motivation policies, a specific study of the decisional road process for leaving a company is needed and welcomed.

After releasing his model of organizational persistence, Peterson (2010) raised a series of limits, one of them specific for the lack of individual factors which might determine turnover taken into account in the current model. Given the data mentioned above, this article aims to test an extension of Peterson's approach (2004) by adding two more personality traits in the model - motivational persistence and authenticity in explaining the job changing intentions and by expanding the time frame of the longitudinal study to a 1 year and a half.

\section{Extending the model and discussing benefits}

\section{Motivational persistence and the organizational experience}

Constantin, Iarcuczewicz, Constantin, Fodorea and Caldare (2007) differentiates between the qualitative aspects of motivation - the motivational engagement's orientation (motivational involvement), and its quantitative aspects, namely the force or the strength of a person's motivation (motivational persistence). This theory proposes the concept of motivational persistence in order to define the "set of skills that helps individuals to reach their goals". Starting from the assumption of the Functional Theory - Ford (1992), Kafner (1999) and Pinder (1998), that claims that work motivation is better represented as a process involving two psychological interconnected systems - choosing the goal and the effort for achieving the goal, Constantin proposes the concept of motivational persistence (Hojbota \& Constantin, 2009) defined as a "stabile trait of the conative system, a person's susceptibility of persisting in his/hers motivation and making efforts to achieving a personal goal". In other words, persistence can be defined as a voluntary sustentation of the actions orientated towards a certain goal despite the obstacles, problems or damps. Neumann, Finlay- Neumann and Reichel (1990) defines motivational persistence as "a person's ability to overcome obstacles and to be perseverant in searching solutions for problems despite hostile circumstances", while Wise (1996) saw it as "the ability to resist the temptation to quit when a sustained effort is needed", and Miceli \& Castelfranchi (2000) defined it as "the quantity of time a person spends with a task". Meier \& Albercht (2003) evaluate persistence as "an observable behavior that determines a person to not give up easily and to make a prologue effort when the tasks become difficult", underlining that some theories treat persistence as a function of motivation, (Tinto, 1992) and others as a key element of individual motivation and not as a behavioral intentions (Bean, 1982). Wise (1996) developed a situational model of motivation and performance in assessment from the perspective of task persistence and Meier \& Abrecht (2003) approached persistence as a part of a behavior oriented toward a certain goal. Others focused on identifying and analyzing factors that can be associated with persistence: locus of control (James, 1984), personality (McGiboney \& Carter, 1993), vocational success (Staw \& Ross, 1980), emotional intelligence (Eysenck, 1953), neurotic impulses (Eysenck, 1953).

Many studies proved that those who expect from the begging to be capable to reach positive outcomes have a high level of persistence while those that expect negative outcomes have a lower level and a tendency to give up especially if they focus their attention on what they feel while doing that activity: frustration, anxiety, discomfort (Carver, Blaney, \&Scheier, 1979; 
Duval, Duval \& Mulilis, 1992). Locke (1997) found that personal self-efficacy leads to a higher level of persistency.

Self-efficacy theory (Bandura, 1997) sustains that successful experiences based on persistence despite obstacles lead to a stronger feel of being capable to succeed. Self-efficacy involved a person's expectation of being capable to reach a goal, a person's possibility of taking control on the necessary actions and the performance in the most efficient way to reach the desired outcome. Peterson (2000) revealed the relationship between optimism and persistence, as optimistic persons have a higher probability to be persistent in their activity than pessimist individuals.

Hojbota \& Constantin (2009) found a connection between tolerance to incertitude and motivational persistence sustained by need for cognition. The last one helps taking the events as opportunities or treats, or transformingan ambiguous situation into o challenge that stimulates the person. Tolerance to ambiguous situations helps a person to overcome obstacles and reaching a higher goal, as it assigns a neutral or insignificant value to that situation.

A more consistent approach of persistence as a personality trait is offered by the BigFive model researchers. They propose personality traits like „Persistence”, ”Industriousness”, „Perseverance” or „Self-Discipline”as part of the big factor named „Consciousness”.

Competence, duty, accomplishment, hard-work, self-discipline deliberation are also part of consciousness as a personality trait. The employee knows the importance of reaching the goal and spends energy, patience and efforts (Burch \& Anderson, 2004) in order to get satisfaction from it. A conscious employee may probably reach a higher level of efficiency. Smithikrai (2004) states a positive relationship between this factor and success, as successful employees have the tendency to move towards their objectives in an effective way. They tend to believe that their work has a special sense and thus, they have a higher level of psychological attachment for their workplace (Li, Lin \& Chen, 2007).

The pursue of goals with a mainly extrinsic content in mind - like status, fame or wealth, tends to be associated with a lower level of psychological health, compared with following goals with a mainly intrinsic content focus - like relationships, development, health or community welfare. The extrinsic motivated pursue leads to an indirect satisfaction of basic psychological needs because they tend to be focused on values associated with external factors like financial wealth, and thus favors social comparisons that lead to excesses (Lyubomirsky \& Ross, 1997), or instable level of self-esteem (Kernis, Brown \& Brody, 2000) which negatively correlates with well-being. Moreover, goals with an external content eliminate many behaviors which are satisfying needs like belonging to a group or pro-social commitment, because they focused on collecting assets and competing (Ryan, Seldon, Kasser \& Deci, 1996).

Following goals with mainly intrinsic content has a positive effect on well-beingbecause it promotes satisfying basic needs like the need for autonomy, competence and relationships. In other words, the natural tendencies for development are encouraged (Shelon, Elliot, Kim \& 
Kasse, 2001).

\section{Motivational Persistence Benefits}

Persistence in related with perseverance and continuity in displaying a behavior or in performing a certain task. It is merely enough for a person to choose a certain direction for his/her emotional involvement and to initiate behaviors according to the goals defined. $\mathrm{He} / \mathrm{she}$ might also need to put to work his/her ability to hang on for a long time in that motivational choice, despite the rut, obstacles, fatigue, disappointments. Motivational persistence is not only behavior perseverance in reaching an established goal but also it refers to the ability to stay motivated (motivationally involved) on longer terms, to find incentive and satisfaction even when accomplishing the task is not a new thing anymore, nor happening soon, and it does not bring satisfaction like in the beginning (Constantin, 2008).

Graves (1995) showed that leaders with a high level of task persistency get more positive assessments from their subordinates, they are perceived as being more responsible and are more suitable for leadership positions than non-persistent leaders.

The relationship between persistence, self-efficacy and the ability to acquire and develop competencies, skills or capabilities is a complex one. As self-efficacy and ability to acquire and develop competencies, skills or capabilities get higher, we can expect a negative correlation between self-efficacy and persistency because success will be easy to reach for those with a high level of efficiency, proficient in acquiring and consolidating new skills. But, if we talk about high difficulty tasks that are beyond the actual level of abilities or competencies, we can expect a positive correlation between self-efficacy and persistence (Henderlong and Lepper, 2002)

Researchers claim that pro-social motivation facilitates a higher level of persistence, performance and productivity because it allows individuals to dedicate themselves to a certain cause, goal (Thompson and Bunderson, 2003) or o moral principle (Shamir (1990), and to take a commitment towards the people that would benefit from their efforts (Meglino and Korsgaard, 2004).

Grant (2008) suggested that pro-social motivation has a higher chance of predicting persistence, performance and productivity when it is associated with intrinsic motivation. He has reached the conclusion that intrinsic motivation strengthens the connection between pro-social motivation and persistence, performance and productivity for firefighters and those that do fund collects (Grant, 2008). Surprisingly, his study revealed a negative correlation between pro-social motivation and the results of persistence when intrinsic motivation had a low level. A theoretic explanation might rely on the fact that people with low intrinsic motivation would experience stress and overloading when making efforts to finish a task which gives no internal reinforcement, satisfaction or pleasure (Bolino and Turnley, 2005). From this perspective, pro-social motivation without intrinsic motivation can consume the psychological resource that a person uses for self-adjustment (Muraven and Baumeister, 200) and this could lead to exhaustion, and thus, a low level of persistence productivity.

The contact between employees and especially with those employees that benefits from their 
work plays a key role in raising the level of persistence. Moreover, the pro-social jobs are structured in such a way that the employees have the opportunity to interact with those who will benefit from their efforts, and these interactions could raise the level of persistence because an affective attachment forms. Thus, we do not need a change in the job structure but it is important that the leaders offer their employees the opportunity to interact with the beneficiaries (Grant et al, 2007).

Eccles \& Wigfield (2002) observed that high goals are associated with the strongest empirical proves and have been correlated with self-competence, building the concept of self, effort attribution, raising the level of persistence in difficult tasks and using cognitive strategies for monitoring and problem solving, a deep analysis of data and self-regulation process.

Tutu \& Constantin (2012) proved the existence of a positive significant relationship between two factor of persistence - goal striving for a long term and striving current goals and work performance. As they have a strong power of prediction, it means that performance could be seen as a function of those individual factors. In other words the persons with a high level of performance follow his/her long term and the short term goals despite the obstacles.

Reviewing all researches presented, we found evidence that motivational persistence is related to various factors, form the organizational dynamic context - like work performance, engagement, relationship with superiors, task involvement, to personality factors that impact the organizational environment dynamics - like self-efficacy, self-esteem, optimism, emotional intelligence and consciousness.

\section{Authenticity in the organizational environment}

In literature, authenticity hasn't drowned much attention and was often integrated in studies about identity. Recently, due to its impact on a person's development and well-being, it started to be the main focus for many researchers (Ilas, 2005; Goldman and Kernis, 2003; Harter, 2002; Sheldon, Ryan, Rawsthorne \& Ilardi, 1997).

Ashton \&Lee (2007) included authenticity in their model of personality as a sixth factor due to its associated concepts: loyalty, positive values, honesty and sincerity. In literature it is associated also with promoting a positive experience, positive personal development, loyalty towards self (Rogers, 1965).

The humanistic perspective on personality considers that there is a true self that comes from self-exploration and self-acceptance and it influences the psychological state of well-being (Hansen, 2005). Thus authenticity is a central concept for the Humanistic School of Psychology which sees it the main lead for human functionality (Horney, 1951, Rogers, 1959).Goldman \& Kernis (2002) defined authenticity as a composite concept that includes self-awareness, self-trust, processing information accurately and self-acceptance. Self-awareness refers to the level of emotion, reasons and desired recognition, while self-development cognitions in order to process information about self in an accurate manner involve a honest and as much as possible objective assessment of personal aspects, positive and negative, qualities and attributes. 
In 2008 authenticity was presented as a dispositional trait that could be understood from a tridimensional perspective which involves a low level of self-alienation (a strong feeling of identity consistent with the strongest beliefs), an authentic living perspective according with this identity and refusing the external influences when they are against a person's own beliefs (Wood, Linley, Maltby, Baliousis and Joseph 2008). Thus, we say about a person that is authentic when she knows its identity and beliefs (low level of self-alienation), acts in accordance with it (high level of living authentic) and leaves other's opinions out if these are not according with his/her beliefs (low level of accepting other's influences). When a person expects to be discriminated or disconsidered because of his/her experiences or stereotypes, he/she will most likely reveal himself/herself as little as possible and he/she will manifest a low level of authenticity (Shelton, Richeson, Salvatore and Trawalter, 2005). If individuals perceive a threat to their status they will display less authenticity in their social interactions, manifesting behaviors opposed to the expected stereotypes (Kaiser \& Miller, 2001). Shelton, Richeson \& Vorauer (2006) noticed that analyzing own actions would induce sometimes censured behaviors in relations with others. Individuals will avoid behaving naturally, if they would think that their behaviors would determine others to perceive them negatively. In professional environment, if the employee expects to interact with persons with a higher status he/she might manifest compensatory attitudes and behaviors. For example, in a performance review session, a woman may believe to be evaluate by a sexist male managers, and thus, she would avoid behaviors that would confirm female stereotypes (Kaiser \& Miller, 2001). Professional opportunities and development are connected to hiding at the workplace. If a person cannot manifest his/her true self in the organization he/she is a part of, he/she could invest an extra energy to pretend, consuming more psychological resources on the way and feeling and feeling more stressed than in authentic displaying contexts. Individuals tend to manifest in accordance with the others expectancies, being less focused on the tasks and less performant. In this context, there are big chances they will think about changing their job.

The high level of competition between companies to attract talents creates the perfect context for them to manifest themselves. If they don't have the possibility of being authentic they can easily find another job or another company where they can feel comfortable. In this dynamic context which encourages employees to reach over their boundaries, we need to think to alternative for those for whom being authentic means being comfortable and in stable environment.

Denying the emotions and thoughts about self or others leads to superficial behaviors and to personal discomfort, and sometimes rejection from the others (Hansen, 2005). Goffman (1959) notices that in unfamiliar situations people tend to practice an impression management and to present themselves in a non-authentic manner in order to gain acceptance from others.

Impression management is a mechanism that people use when they plan their actions, preserver and are sociable. The tendency to present themselves in a positive manner is most often seen in those with a low level of self-esteem and with an extremely high level of self-esteem. It is a deliberate and voluntary act that has the goal to create a positive image of self (Tudose, Macarie, Astani, Maxim, Sava et al., 2009). 
For every person it is important to be perceived by others in a positive way and to hide as good as possible their negative aspects (Nae, 2006).

How an employee can be authentic and serve the company's goals is an important subject for researchers and not only. Few researches used this factor as a study variable in their studies. The results published until now found that authenticity is valuable for an organization more than as an indicator of well-being and efficacy of leadership (Knoll and Van Dick, 2013). Considering authenticity may extend actual knowledge about how employees express themselves, organizational identification and interactions between those factors.

Authenticity emphasizes the complexity of human experience. It addresses the way we can avoid labels for a certain social role in favor of a larger concept of self and authenticity. This is the heart of diversity, concept embraced by organizations that what to offer their employees equal chances no matter the age, gender, religion nor nationality. Authenticity as a partial mediator between the opportunity to express freely and actual freedom of expression indicates that the environmental factors can facilitate authenticity.

In being authentic at work, a leader's emotional maturity means the development of at least three components specific to emotional intelligence: self-consciousness defined as the ability to acknowledge and understand the state of mind, emotions and their effect on others (Goleman, 2014); empathy defined as the ability to consider others emotions especially in making decisions and self-regulation defined as the ability to control and redirect destructive emotions and impulses and the ability to adapt to changes. Thus the essence of employee's authenticity is their leader's authenticity. Leader's authenticity is strongly related to well-being (Menard \& Brunet, 2011).

Yammarino et al. (2008) found that if authenticity is supported as a prototype behavior for the team it will lead to a higher level of authenticity in the team as with time the members to the team will be more open, transparent, balanced and moral in their behavior. They will be more authentic in order to be more like the others according to social identification theory (Hogg and Abrams, 1988) thus having a better understanding of them as a team and a higher level of trust and a positive identity as a team. Authentic behavior promotes efficient relationships (Gardner, Avolio, Luthans, May \& Walumba, 2005; Ilies, Morgeson \& Nahrgang, 2005) and determines an enhancement in team functionality and productivity. Gardner et al. (2005) and Ilies et al. (2005) found that authentic leaders have a role in encouraging the authentic of their employees in time trough positive modeling. Authentic leaders and their employees interact as a duo and as a group and strengthen the authenticity development in each other thus forming more authentic relationships. Authenticity is assumed by a person if the self-consciousness of their thoughts and actions and also the social context indicate positive perspectives (Mendoza-Denton, Downey, Purdie, Davis and Pietrzak 2002).

Gardner et al. (2005) and Ilies et al. (2005) presented more complex models of authentic leadership: authentic leaders offer support for their employee's development in selfdetermination and psychological engagement and have a positive influence on their attitude and civic behavior, creativity and well-being. A large number of researchers found that authenticity has positive effects on a large area of work outcomes (Grandey, Fiske, Mattila, 
Jansen \& Sideman, 2005; Sosik, Jung \& Dinger, 2009; Walumbwa, Wang, Wang, Schaubroeck \& Avolio, 2010). The predictive value of authentic leadership for the psychological capabilities of the employees is also important because those are connected to work satisfaction, organizational engagement, happiness in the organizational context, role performance and extra role performance (Avey, Wernsing \& Luthans, 2008; Luthans, Avolio, Avey \& Norman, 2007; Luthans, Norman, Avolio \& Avey, 2008; Youssef \& Luthans, 2007).

\section{Authenticity benefits}

Authenticity helps promoting an organizational clime where everybody feels safe to be authentic. This does not mean revealing too many things about themselves but enough to create trust for developing the maximum of potential.

The interaction between organizational identification and authenticity suggests that a high level of authenticity is not only tied to social influences and community but might also work in the same way with organizational goals and values (Knoll \& Van Dick, 2013). Madera et al. (2012) found that, in an organizational environment, the efforts to suppress their identity was perceived by their 211 subjects as motive for discrimination, low levels of work satisfaction and intention to change jobs. Thus the employees that feel they can be authentic at work will have better relationships with their colleagues, a higher level of work satisfaction and will be more likely to stay in the organization for a long time.

Grandey (2003) and Hewlin (2009) found that employees often need to behave in a certain way and that adjusting they behavior according with others expectations will lead to a better evaluation from their leaders (Blickle et al., 2011). Many organizations have their own culture and values and promote certain behaviors accepted at work. Thus companies need a recruitment process focused on quality and compatibility between a candidate's authenticity and organizational expectations. If they do not match in terms of values and accepted behaviors it may lead to problems in the integration period, a low level of performance and turnover. Non authentic employees can be toxic and can determine a lower level of authenticity in their team. Authenticity in team members leads to positive work behaviors and productivity (Hannah et al, 2011). Thus promoting authentic behavior in organization can be a task for all parties involved in human resources management and not only for the recruiting team.

Recent studies found that there is a link between authentic behavior and psychological health (Lakey \& Davis, 2005, Kernis \& Goldman, 2006). People with a low tendency to be authentic have more negative emotional experiences, a low self-esteem a higher level of stress (Kernis \& Goldman, 2006). Wood et al. (2008) found that authenticity is positively related to psychological well-being. Wright \& Bonnett (2007) found that well-being moderates the relationship between professional satisfaction and turnover: there is a negative correlation between satisfaction and turnover for those with a high level of well-being.

Authenticity is a process of self-development in which a person discovers his/her true self and accepts it and behaves accordingly. (Kernis \& Goldman, 2006). This process starts in adolescence and continues as a person's grows and shapes their identity (Harter, 2002). Reich, 
Harber \& Siegel (2008) found that developing an authentic self, lowers the level of stress in times of change. Authenticity involves not only presenting one's self in a consistent manner (being yourself) but also behaving in a self-determined and autonomic manner (Deci and Ryan, 2000; Goldman \& Kernis, 2002). An authentic person is honest and does not assume qualities and beliefs that don't belong to him/her (Harter, 2002) and its loyal to his/her values system (Avolio, Gardner, Walumbwa, Luthans \& May, 2004,).

Being authentic is a trait similar to the ability of making career decisions (White \& Tracy, 2011). Authenticity can be defined as a way of living accordingly with interior experience (psychological state, thoughts, feelings) and involves being open, honest in the exterior behavior and in how a person communicates with others (Kernis \& Goldman, 2006; Ryan $\&$ Deci, 2000; Wood, Maltby, Caliousis, Linley \& Joseph, 2008). Those with a high level of authenticity have a lower level on indecision regarding their career. The correlation between authenticity and goal instability suggests that those with a higher level of authenticity have a lower probability to lack goals and motivation regarding projects and other aspects from work (White \& Tracy, 2011). Research on career planning showed that those with a higher level of authenticity choose carefully their job (With \& Tracy, 2011). A carefully chose job is a better match with the employees needs and offers the resources expected (NG and Feldman, 2012).

Authentic people (Folkman and Lazarus, 1980) most often apply coping strategies oriented towards problem solving (like actively involving in solving problems or modifying the sources that affect their well-being) and rarely coping strategies that do not help them adapt (cognitive or behavioral disagreement or dinning the existence of stress).

Authenticity promotes well-being and influences self-esteem thus leading to health (psychological and physical) and satisfaction leading to low levels of absenteeism, turnover and other negative phenomena. Organizations could implement specific programs for increasing the authenticity for leaders and for team members as well: developing self-consciousness and transparency trough feedback, reflection and other identity developing processes; increasing moral perspectives by implementing moral development programs (Gardner et al, 2005; Lord \& Brown, 2004).

Given this benefits, we believe that the extended model proposed will increase the power of predictability for the Organizational Model of Employee Persistence, helping both managers and employees to find their win-win collaboration. Future empirical validation is required so that the theoretical model proposed, can prove its high scientifically utility.

\section{REFERENCES}

Abele, A. E., Spurk, D. (2009). The longitudinal impact of self-efficacy and career goals on objective and subjective career success. Journal of Vocational Behavior, 74, 53-62.

Acton, T., Golden, W. (2002). Training: the way to retain valuable IT employees. Informing Science.

Alias, N. E., Nor, N. M., Hassan, R. (2014). The Relationships Between Talent Management Practices, Employee Engagement and Employee Retention in the Information and Technology (IT) Organizations in Selangor. 2014 AAGBS International Conference on 
Business Management (AiCoMB 2014).

Bailey, J. L., Stefaniak, G. (2002). "Preparing the Information Technology Workforce for the New Millennium, ACM SIGCPR Computer Personnel, 20, 4-15.

Betz, N. E., Hackett, G. (2006). Career self-efficacy theory: back to future. Journal of Career Assessment, 14, 3-11.

Bishop-Clark, C., Wheeler, D. (1994). The Myers-Briggs personality type and its relationship to computer programming. Journal of Research on Computing Education, 26(3), 358-370.

Boroş, S., Curșeu, P. L. (2013). Is it here where I belong? An integrative model of turnover intentions. Journal of Applied Social Psychology2013, 43, 1553-1562.

Boswell, W. R. , Shipp, A. J, Payne, S. C., Culbertson, S.S. (2009). Changes in newcomer job satisfaction over time: examining the pattern of honeymoon and hangover. Journal of Applied Psychology, vol.94, No.4, 844 - 858.

Brown, Bettina Lankard. (1998). Career mobility, a choice or necessity? Columbus, OH : ERIC Clearinghouse on Adult, Career and Vocational Education, Center on Education and Training for Employment, College of Education, the Ohio State University.

Burch, G., St. J. Anderson, N. (2004). Measuring person-team fit: development and validation of the team selection inventory. Journal of Managerial Psychology, 19 (4), 406 - 426.

Bryson, A., Forth, J., Stokes, L. (2015). Does Worker Wellbeing Affect Workplace Performance? CEP Discussion Paper No 1363.

Constantin, T. (2009). Determinanţi ai motivaţiei în muncă - de la teorie la analiza realităţii organizaţionale, Editura Universităţii Alexandru Ioan Cuza, Iași.

Di Paula, A., Campbell, J. D. (2002). Self-esteem and persistence in the face of failure. Journal of Personality and Social Psychology, 83, 711-724.

Döckel, A., Basson, J. S, Coetzee, M. (2006). The effect of retention factors on organisational commitment: an investigation of high technology employees. SA Journal of Human Resource Management, 4 (2), 20-28.

Duval, T. S., Duval, V. H., Mulilis, J. P. (1992). Effects of self-focus, discrepancy between self and standard, and outcome expectancy favorability on the tendency to match self to standard or to withdraw. Journal of Personality and Social Psychology, 62, 340-348.

Enns, H. G., Ferratt, T. W., et al. (2006). Beyond Stereotypes of IT Professionals: Implications for IT HR Practices. Communications of the ACM 49 (4): 106-109.

Fowler, A. (1996). Employee Induction: a Good start (3rd edition). London: Institute of Personnel and Development.

Grant, M. A., Campbell, M. E., Chen, G., Cottone, K., Lapedis, D., Lee, K. (2007). Impact and the art of motivation maintenance: The effects of contact with beneficiaries on persistence behavior. Organizational Behavior and Human Decision Processes, 103, 53-67.

Griffeth, R. W., Hom, P. W., Gaertner, S. (2000). A meta-analysis of antecedents and correlates of employee turnover: Update moderator tests, and research implications for the next millennium. Journal of Management, 26, 463-488.

Griffeth, R. W., Maertz Jr. C. P. (2004). Eight Motivational Forces and Voluntary Turnover: A Theoretical Synthesis with Implications for Research. Journal of Management, 30(5), 
$667-683$.

Groysberg, B. (2010). Chasing Stars: The Myth of Talent and the Portability of Performance, Princeton, NJ: Princeton University Press.

Heilmann, S. G., Holt, D. T., Rilovick, C. Y. (2008). Effects of Career Plateauing on Turnover: A Test of a Model. Journal of Leadership and Organizaţional Studies, 15(1), 59-68.

Holtom, B., Mitchell, T. R., Lee, T., Eberly, M. (2008). Turnover and Retention Research: A Glance at the Past, a Closer Review of the Present, and a Venture into the Future. The Academy of Management Annals, 2 (1), 231-274.

Hoonakker, P. L. T., Carayon, P., Schoepke, J., Marian, A. (2004a). Job and organizational factors as predictors of turnover in the IT work force: differences between men and women. Proceedings of the WWCS 2004 Conference, Kuala Lumpur, Malaysia.

Jepson, K. (2004). Stress and IT. Credit Union Journal. p. 14.

Joo., B. K, Hahn, H. J., Peterson, Shari L. (2015). Turnover intention: the effects of core self-evaluations, proactive personality, perceived organizational support, developmental feedback, and job complexity. Human Resource Development International, 18:2, 116-130.

Joseph, D., Ng, K. Y., Koh, Ang, S. (2007). Turnover of Information Technology Professionals: A Narrative Review. Meta-Analytic Structural Equation Modeling, and Model Development. 31, No. 3, 547-577, published by Management Information Systems Research Center, University of Minnesota.

Kammeyer-Mueller, J. D., Wanberg, C. R., Glomb, T. M., Ahlburg, D. (2005). The role of temporal shifts in turnover processes: It's about time. Journal of Applied Psychology, 90, 644-658.

Kanfer, R. (1999). Measuring Health Worker Motivation in Developing Countries. Major Applied Research 5. Working Paper 1. Bethesda, MD: Partnerships for Health Reform Project, Abt Associates Inc.

Lee, T. W., Mitchell, T. R. (1994). An Alternative Approach: The Unfolding Model of Voluntary Employee Turnover. Academy of Management Review (19:1). 51-98.

Lent, R., Brown, S., Hackett, G. (1994). Toward a unified social cognitive theory of career academic interest, choice and performance. Journal of Vocational Behavior, 45, 79-122.

Lounsbury, J. W., Sundstrom, E., Levy E. E, Gibson, Lucy W., (2014). Distinctive Personality Traits of Information Technology Professionals. Computer and Information Science; Vol. 7, No. 3.

March, J., Simon, H. A. (1958). Organizations. Wiley, New York.

Mayer-Schönberger, V., Cukier, K. (2014). Big Data: A Revolution that Will Transform How We Live, Work, and Think. Publisher John Murray, London.

McKnight, D. H., Phillips, B., Hardgrave, B. H. (2009). Which reduces IT turnover intention the most: Workplace characteristics or job characteristics?. Elsevier Journal, Information and Management, 46, 167-174.

Mobley, W. H. (1977). Intermediate Linkages in the Relationship between Job Satisfaction and Employee Turnover. Journal of Applied Psychology (62:2). 237-240.

Mossholder, K. W., Settoon, R. P., Henegan S. C. (2005). A relational perspective on tunover: examining structural, attitudinal and behavioral predictors. Academy of Management 
Jurnal, 48, no. 4, $607-618$.

Peterson, S. L. (2004). Toward a Theoretical Model of Employee Turnover: A Human Resource Development Perspective. Human Resource Development Review, 3(3), 209-228.

Peterson, S. L. (2007). Managerial turnover in US retail orgnizations. Journal of Management Development, Vol.26, No.8

Peterson, S. L. (2009).Career Decision-Making Self Efficacy, Integration, and the Likelihood of Managerial Retention in Governmental Agencies. Human Resource Development Review, Vol.20, No.4

Popa, M. (2011). "Infidelitățile" coeficientului de fidelitate Cronbach alfa. Psihologia resurselor umane, Vol. 9, Nr. 1, pp. 85-99.

Rolandsen, L. A. (2013). Gender Equality, Intersectionality, and Diversity in Europe (The Politics of Intersectionality), New York: Palgrave Macmillan.

Royal, C., Althauser, R. P. (2003). The labor markets of knowledge workers: IT' careers in the wake of corporate restructuring. Work and Occupations, 30. 214-233.

Rynes, S., L. Colbert, A. E and Brown, K. G. (2002). HR Professionals' Beliefs About Effective Human Resource Practices: Correspondence Between Research And Practice. Human Resource Management, Wiley Periodicals, Summer 2002, 41, No. 2, 149-174.

Salanova, M., Pero, J. M., Schaufeli, W. B. (2002). Self-efficacy specifity and burnout among information technology workers: an extension of the job demand-control model. European Journal of Work and Organizational Psychology, 11, 1-25.

Stajkovic, A. D., \& Luthans, F. (1988). Self-efficacy and work-related performance: A meta-analysis. Psychological Bulletin, 124(2), 240-261.

Steel, R. P. (2002). Turnover theory at the empirical interface: Problems of fit and function. Academy of Management Review, 27: 346-360.

Steers, R., Mowday, R. T. (1981). Employee Turnover and Post Decision Accommodation Processes, in Research in Organizational Behavior (3). L. L. Cummings and B. Staw (eds.). JAI Press, Greenwich, CT, 235-281.

Tanova, C., Holtom, Brooks C. (2008). Using job embeddedness factors to explain voluntary turnover in four European countries. The International Journal of Human Resource Management, 19, No. 9, September 2008, 1553-1568.

Tinto, V. (1982). Limits of Theory and Practice in Student Attrition. Journal of Higher Education. 53, Issue 6, 687-700.

Tremblay, M., Chenevert, D. (2008). Influence of Compensation Strategies in Canadian Technology-Intensive Firms on Organizational and Human Resources Performance. Group and Organization Management.

Tudose, O., Macarie, A. E., Astani, A., Maxim, A. E., Sava, A., Ungurean, A. L. (2009). Dezirabilitatea socială. Relaţiile constructului cu stima de sine, stilul de atribuire şi factorii modelului Big Five. Psihologie aplicată: Diversitate şi consistenţă, 687-710.

Țuţu, A., Constantin, T. (2012). Understanding job performance through persistence and job competency. Procedia - Social and Behavioral Sciences, 33, 612 - 616.

\section{Copyright Disclaimer}


Copyright reserved by the author(s).

This article is an open-access article distributed under the terms and conditions of the Creative Commons Attribution license (http://creativecommons.org/licenses/by/3.0/). 